\title{
Lysine requirement of the finishing pig according to sex
}

\author{
D. BOURDON, Y. HENRY
}

Institut National de la Recherche Agronomique, Station de Recherches porcines, Saint-Gilles, 35590 L'Hermitage

The lysine requirement of the finishing pig was studied in an experiment involving 120 LargeWhite female and castrated male pigs between 49.3 and $100.4 \mathrm{~kg}$ live weight. Six treatments including increasing supplementary levels of lysine in pure form (0.52 to $0.90 \mathrm{p}$. 100) of the diet were compared. The animals were fed the same level of diet according to live weight, representing around three times the level at maintenance. The basal diet, including wheat, soybean meal and peanut meal, contained 15.5 p. 100 crude protein and 3.17 Mcal digestible energy (DE) $/ \mathrm{kg}$. The maximum average daily gain of muscle, which was used as the criterion for determining the requirement, was obtained with 0.75 and 0.67 p. 100 lysine in the diet in females and castrated males, respectively. This requirement corresponded to a level of performance of $850 \mathrm{~g}$ live weight gain per day and $50-52$ p. 100 and $47-49$ p. 100 of muscle in the carcass in females and castrated males, respectively. From this result, it may be concluded that the optimum level of lysine in a practical wheat-soybean meal diet, without supplementary addition, is $0.80 \mathrm{p}$. 100 in females $(2.5$ $\mathrm{g} / \mathrm{Mcal} \mathrm{DE}$ or $0.6 \mathrm{~g} / \mathrm{MJ} \mathrm{DE})$ and $0.70 \mathrm{p}$. 100 in castrated males $(2.2 \mathrm{~g} / \mathrm{Mcal} \mathrm{DE}$ or $0.53 \mathrm{~g} / \mathrm{MJ}$ DE), when both sexes are fed the same level of diet close to ad libitum.

\section{Effect of dietary lysine level and environmental temperature on the performance of growing-finishing pigs}

\section{J. LE DIVIDICH, Dominique RINALDO} Institut National de la Recherche Agronomique, Station de Recherches porcines,
Saint-Gilles, 35590 L'Hermitage

A trial involving 54 castrated male Large-White pigs was conducted to determine the interactive effects of environmental temperature $\left(12,20\right.$ and $\left.28{ }^{\circ} \mathrm{C}\right)$ and dietary lysine level $(0.63$ 0.79 and 0.95 p. 100 during the growing period and $0.54-0.67$ and 0.84 p. 100 during the finishing period) on the performance of pigs between 29.4 and $92.2 \mathrm{~kg}$. The animals were housed individually on concrete slatted floors and received the same amount of feed at the 3 temperatures. Increasing the temperature improved daily gain by $102 \mathrm{~g}$ between 12 and $20^{\circ} \mathrm{C}$ and by $29 \mathrm{~g}$ between 20 and $28^{\circ} \mathrm{C}$ (quadratic effect of temperature, $\mathrm{p}<0.05$ ). There was an interactive effect of environmental temperature and dietary lysine level on daily gain. During the growing period, there were significant differences between the daily gains provided by the extreme levels of lysine only, whereas at $28^{\circ} \mathrm{C}$ daily gain was improved for each lysine level $(p<0.05)$. During the finishing period, daily weight gain was not influenced by dietary lysine level at $12{ }^{\circ} \mathrm{C}$; at 20 and $28^{\circ} \mathrm{C}$ lysine level had a quadratic effect on daily gain $(\mathrm{p}<0.01)$. The dietary lysine level required to maximize growth rate and feed efficiency corresponded to $0.67 \mathrm{p} .100$. The increased lysine levels improved muscle percentage in the carcass and daily gain of muscle (quadratic effect of lysine, $\mathrm{p}<0.05$ ). The results suggest that the optimum lysine level is closely related to dietary energy available for growth. 